TEME, г. XLII, бр. 3, јул - септембар 2018, стр. 727-740

Оригинални научни рад

DOI: $10.22190 /$ TEME1803727J

Примљено: 27. 6. 2017.

UDK 159.922 .8

Ревидирана верзија: 25. 3. 2018.

Одобрено за штампу: 12. 6. 2018.

\title{
PERSONALITY, COGNITION AND LIFE EVENTS AS PREDICTORS OF EMOTIONAL DISTRESS IN ADOLESCENCE
}

\author{
Mia Marić*, Marija Sakač \\ University of Novi Sad, Faculty of Education in Sombor, Sombor, Serbia \\ *mia.maric@pef.uns.ac.rs
}

\begin{abstract}
The aim of this research was to examine the contribution of personality, cognitive style and life events to the prediction of the symptoms of emotional distress in adolescents. The sample consisted of 300 adolescents. In the analysis, the indicators of five personality dimensions were included - Neuroticism, Extraversion, Openness, Agreeableness and Conscientiousness, indicators of attribution dimensions- controllability, internality, stability and the global nature of causes, and importance of the situation, the number, type and occurrence period of life events, and the severity of symptoms of emotional distress in adolescents.

Life events have proved to be the best predictors of the symptoms of distress in adolescents. The most significant contribution to the occurrence of distress provided the total number of events. The probability of the occurrence of distress increases with the occurrence of chronic stressors and family problems. Significant contributors to the prediction of distress are also the dimensions of personality - Agreeableness and Conscientiousness, and attribution dimensions - externality and the importance of negative situations.
\end{abstract}

Key words: adolescence, personality traits, attributional style, life events, emotional distress.

\section{ЛИЧНОСТ, КОГНИЦИЈА И ЖИВОТНИ ДОГАЪАЈИ КАО ПРЕДИКТОРИ ЈАВЉАЬА ЕМОЦИОНАЛНОГ ДИСТРЕСА НА АДОЛЕСЦЕНТСКОМ УЗРАСТУ}

\section{Апстракт}

Циљ рада је испитивање доприноса особина личности, когнитивног стила и животних догађаја предвиђању симптома емоционалног дистреса код адолесцената. Узорком је обухваћено 300 испитаника. У анализу су уврштени показатељи пет димензија личности: Неуротицизма, Екстраверзије, Отворености, Пријатности и Савесности; атрибуционих димензија: контролабилности, интерналности, стабилности, глобалности узрока и значајности ситуација, број, врста и време јављања 
животних догађаја, као и степен изражености емоционалног дистреса код адолесцената.

Најзначајнијим показатељима предвиђања емоционалног дистреса код адолесцената показали су се животни догађаји, при чему највећи допринос појави дистреса пружа укупан број догађаја. Могућност појаве емоционалног дистреса повећава се са појавом хроничних стресора и породичних проблема. У значајној мери су са појавом дистреса повезане и димензије личности Пријатност и Савесност, као и атрибуционе димензије екстерналност и значајност за негативне ситуације.

Кључне речи: адолесценција, особине личности, атрибуциони стил, животни догађаји, емоционални дистрес.

\section{INTRODUCTION}

Hall describes adolescence as the period of "storm and stress", the phase of conflict and unrest when it comes to the expression of extremes in emotions and mood (Hall, 1904, according to Wenar, 2003). Negative emotions lead to the emergence of general nervous tension in adolescents, which is reflected in a series of behavioral symptoms, such as aggressive behavior, the use of psychoactive substances, juvenile delinquency, etc. (Wenar, 2003).

Emotional distress refers to the set of affective and behavioral responses, accompanied by physiological symptoms, which lead to relatively permanent difficulties in emotional and intellectual functioning (Marić, 2009; Zotović, 1999). The emotional-behavioral indicators of distress include hyperactivity, reddening of skin, confusion, mistakes in speech, preoccupation with the situation, irritability, accentuated feelings of fear and insecurity, apathy and lack of energy, tearfulness, tumultuous outbursts of emotion and compulsive actions (Burns, 1997; Bensaba, 1999; Tucker, 2000).

The diathesis-stress model points out that the phenomenon of negative emotional reactions in adolescence has a complex nature, and that it is affected by a larger number of internal (personal characteristics, cognitive processes) and external factors (stressful experience, inadequate support from the environment) (Joiner \& Schmidt, 1995; Sameroff, 2000). Major life events and daily stressors, are described as triggers of adverse emotional reactions, while internal factors, such as stable personality traits and cognitive style, are presented as vulnerability factors that create individual differences in the probability of occurrence, in the type of manifestation and in the method of overcoming such reactions (Cuffe, McKeown, Addy, \& Garrison, 2005; Utsey, Giesbrecht, Hook, \& Stanard, 2008). Personality traits and cognitive style also present potential protective factors in the model assumptions. As for the non-clinical population of young people, stressful events are considered to be the most important factors that lead to negative emotional reactions (Schmidt \& Joiner, 1995; Steinhausen, Haslimeier, \& Metzka, 2007). 
The results show that within the dimensions of the "Big Five" model of personality (Goldberg, 1990), Neuroticism highly positively correlates with negative affectivity- NA (measuring distress, dissatisfaction) and Extraversion with positive affectivity- PA (the factor of general satisfaction) (Costa \& McCrae, 1980; David, Green, Martin, \& Suls, 1997; Lucas \& Baird, 2004; Lucas \& Fujita, 2000). Openness to experience, Agreeableness and Conscientiousness are usually positively related to PA, and negatively with NA (Aliik \& Realo, 1997; McCrae \& Costa, 1991; Watson \& Clark, 1992). The dimension of Agreeableness describes behavior in social relations. The high scores are achieved by the people of sensitive and gentle nature, to whom good relationships with others are very important. They are also prepared to subordinate their personal desires to the expectations of the environment (Smederevac, 2000). Conscientious people are oriented towards achievements and results, and are entirely dedicated to goals (Harris \& Lucia, 2003).

The appearance of negative emotional reactions in adolescents is largely under the influence of cognition and perception of the situation (Lazarus \& Folkamn, 1984; Silver \& Worthman, 1979; Tucker, 1996; van Niekerk et al., 2016). Attribution style represents a consistent and permanent way of attributing the causes of events (Novović, Biro, Smederevac, \& Kosanović, 2001). Weiner says that the observed causes can be compared to the three dimensions: internality, stability and controllability, while Seligman's school controllability is replaced by the dimension of globality (Abramson, Seligman, \& Teasdale, 1978). Peterson and Seligman differentiate pessimistic and optimistic attribution style (Peterson \& Seligman, 1984, according to Hjelle, 1992). Pessimistic style is characteristic of people who see the cause of negative events as internal, stable and global, and the causes of positive events as external, specific and unstable, and it is considered that it significantly contributes to negative emotional responses (Burns \& Seligman, 1991; Seligman 1978). Diathesis-stress models often cited external locus of control as the factor that predisposes the young for the high rate of negative affective responses (Sameroff, 2000). The findings of the studies confirm that the external locus of control is more "unhealthy" and non-preferred for the mental health (Paykel, 1982; Zotović, 1999). The propensity of attributing of particular significance to certain situations in life, positive or negative, increases emotional distress and tension when person dealing with these situations (Novović \& Biro, 1996), which facilitates the detection of symptoms distress.

Life events are described as an objective experience that interferes with the normal activities of the person, requesting a change in its adjustment. They always have a subjective meaning, and constitute a trigger for the emergence of various difficulties on the affective level. Within the negative effects, the manifestations of emotional distress in psychological and physiological domain predominantly occur (McCullough, Huebner, \& 
Laughlin 2000; Zotović, 1999). The number of stressful experiences is a more significant predictor of the onset of the symptoms of emotional distress than the type of stressors (Rutter, 1981; Sameroff, 2000). Chronic stressors are particularly risky, which may not be of great intensity, but by continuously repeating exhaust defence potential of individuals (Tucker, 1996).

The emergence of emotional difficulties in the adolescent age is determined by a number of psychosocial determinants, and of immense importance is the consideration of the complex influence of characteristic of external events, subjective assessments of events and individual ways of reacting (Karevold, 2008; Krackow \& Rudolph, 2008). The results of studies indicates that in the non-clinical population of the youth, the appearance of negative emotional responses is to the maximum extent caused by the action of external factors- major events and daily stressors specific to this stage of development (misunderstandings with parents, teachers, peers, problems at school, unlucky in love), which in adolescence receive primary character (Conger, Elder, Kim, \& Lorenz, 2003; Harkness, Lumley, \& Truss, 2008; Rutter, 1981; Starr \& Joanne, 2008). In this regard, of particular risk are the stressors that come from family, and are thus at a high risk of developing distress among young people growing up in incomplete families and in families where with poor relations between members. The risk are overly restrictive parents, the lack of emotional warmth in the family, neglecting and abuse, given that in such circumstances the family does not provide adequate support (Graber, 2004; Petersen, Compas, \& Brooks-Gun, 1992). However, the manner in which the adolescent see and overcome difficulties, to a large extent depends on their personality traits (Larsen \& Ketelaar, 1991; Headey \& Wearing, 1989; Petroska-Beška et al., 1995), and specific cognitive style that influence the perception of events (Graber, 2004; Joiner \& Wagner, 1995; Rudolph \& Clark, 2001; Stark, Humphrey, Laurent, Livingston, \& Christopher, 1993).

The aim of this research is to determine the contribution of the personality dimensions, attribution style and life events to prediction of the symptoms of emotional distress in the adolescent age. If the research confirms the relation of these three groups of factors with the occurrence of emotional distress in adolescents, and determines which group of factors makes the most significant contribution to the prediction of such a response, it opens the possibility of a better planning of prevention activities.

\section{METHODS}

Participants

The sample consisted of 300 adolescents. The sample consisted of 116 male adolescents (39\%) and 184 adolescent females (61\%). The total 
sample consisted of 163 students of second grade (54\%) and 137 students of third grade $(46 \%)$ of secondary school.

In terms of their academic achievement at the end of the semester, the majority of the surveyed adolescents ended the first half with a very good grade- the total of $108(36 \%)$, followed by the excellent students 86 respondents $(29 \%)$, there were 62 tested subjects $(20 \%)$ who failed at the end of the first half and 41 respondents (14\%) finished the semester with the good average grade; there were only 2 students with the sufficient average grade $(0.7 \%)$.

\section{Measures}

Big Five (BFI). The domain of personality is described by the five variables, obtained by the "Big Five" questionnaire (BFI by John, Donahue, \& Kentle, 1991): Neuroticism, Extraversion, Openness, Agreeableness and Conscientiousness. BFI consists of 44 items and uses short phrases that are descriptions of personality. The task for the respondents is to estimate to what extent they agree with the every statement on the five-point Likert-type scale. In this research the instrument showed satisfactory psychometric properties. Cronbach's $\alpha$ coefficient of the internal consistency for individual subscales in this study ranged from 0.85 to 0.89 .

Attribution Style Questionnaire (ASQ). The space of attribution style is presented across ten variables measured by the Attribution Style Questionnaire (ASQ)- internality, stability, globality and the significance of positive and negative situations (Peterson, Semmel, von Baeyer, Abramson, Metalsky, \& Seligman, 1982). This questionnaire consists of 12 hypothetical situations- 6 positive and 6 negative. The task is to guess what might be the cause of any of the situations and to complete a specific response to the fivepoint Likert scale for each of the four dimensions of the attribution style, and then the significance of the situation. The instrument showed satisfactory psychometric properties in this study. Cronbach's $\alpha$ coefficient of internal consistency of the individual subscales ranging from 0.81 to 0.84 .

Risc Scale. The space of life events is described by the variables measured by Risk Scale, such as the total number of events, time of occurrence and type of event. The scale was formed by modifying the instrument Risk Scale (Grossman et al., 1990). Questions are related to life events that are considered to cause the most common problems in young people's everyday functioning. The task for respondents is to answer to every question with yes or no, depending on whether they experienced the offered experience. According to the type, events can be grouped into the following categories: risk factors related to family environment, health problems, loss, love problems, school problems and conflicts. In this study, the scale included a supplementary column which showed the time of the occurrence of the event. According to the reporting time, the stressors are categorized as follows: 1) current - acting now, at this moment, 2) chronic stress sources - 
constantly are present or occur frequently, 3 ) recent events - from the nearer past, and 4) long ago events.

Depression, Anxiety, Stress Scale (DASS-21). The degree of the emotional distress among the respondents was measured by Depression, Anxiety, Stress Scale, DASS-21 (Lovibond \& Lovibond, 1995). It is operationalized by the degree of the recent emotional distress on the distress subscale of the questionnaire. DASS consists of three self-describing scalesanxiety, distress and depression. The scale of emotional distress is sensitive to the degree of chronic non-specific arousal, and it registers general nervous tension, speed and ease with which a person is aroused and troubled, irritability and a tendency overreacting, impatience and difficulties when trying to relax (Szabó \& Lovibond, 2006). The respondents were asked to mark their emotional experience on a four-level continuum described in each item during the past week. Cronbach's $\alpha$ coefficient of internal consistency of individual subscales in this study ranged from 0.83 to 0.91 .

\section{Procedure}

A correlative research design without repeated measurements was organized. Testing was conducted in groups, during the school classes. Each group was composed by one of 12 school classes included in the survey.

\section{Data analysis}

The statistical method of Pearson correlations and multiple regression analysis was applied for the data analysis.

\section{RESULTS}

Table 1 shows the descriptive indicators of the total score of the respondents on the subscale of emotional distress of DASS-21 questionnaire, which registered the presence and degree of severity of the symptoms of emotional distress in adolescents during the past week.

Table 1 Means, standard deviations, maximum and minimum response of the respondents on the subscale of emotional distress of the DASS questionnaire

\begin{tabular}{cccccc}
\hline & $\mathrm{N}$ & Min & Max & M & SD \\
\hline Degree of emotional distress & 297 & .00 & 21.00 & 9.4276 & 5.63192 \\
\hline N- number of participants; Min- minimum; Max- maximum; \\
M- mean; SD- standard deviation
\end{tabular}

The table above shows that the average scores on the subscale of emotional distress of the respondents is $9.43(\mathrm{SD}=5.63)$, which is a significantly high score, especially because this is a non-clinical population of young respondents (Lovibond \& Lovibond, 1995). 
Table 2 shows a statistically significant Pearson's correlation coefficients between the summation scores on the basic dimensions of personality inventory BFI, summation scores on the ASQ questionnaire dimensions of internality, stability, globality and significance- particularly for positive and negative situations, and for the variables measured by Risk scale that represent dimensions of life events, and the degree of severity of emotional distress among the respondents on the other side. The only variables presented in the table are those which are statistically significant correlates of emotional distress.

Table 2 Significant Pearson's coefficients of correlation of basic dimensions of personality, attribution style and life events and symptoms of emotional distress

\begin{tabular}{lcc}
\hline Emotional distress & $\mathrm{r}$ & $\mathrm{p}$ \\
\hline Agreeableness & .267 & .000 \\
Conscientiousness & .181 & .002 \\
Internality of negative situations & -.133 & .022 \\
Significance of negative situations & .139 & .016 \\
Total number of events & .845 & .000 \\
Chronic stressors & .741 & .000 \\
Family problems & .752 & .000 \\
\hline
\end{tabular}

In multiple regression analysis, the criterion was the summation score of the respondents on the subscale of emotional distress of DASS-21 questionnaire, and the set of predictors were: summation scores on the dimensions of inventory BFI, summation scores on the questionnaire ASQ, and variables measured by the Risk Scale, which represent the dimensions of life events- the total number of events, the time of occurrence and the type of event. These scores had previously been centred; the variables could therefore enter into a unique regression (Belsley, Kuh, \& Walsch, 2004). Tables 3 and 4 show the results of the multiple regression.

Table 3 The coefficient of multiple correlation and the assessment of the significance of the regression model

\begin{tabular}{cccccc}
\hline $\mathrm{R}$ & $\mathrm{R}^{2}$ & Adjusted $\mathrm{R}^{2}$ & Std. error & $\mathrm{F}$ & $\mathrm{p}$ \\
\hline .867 & .752 & .721 & 2.34472 & 19.225 & .000 \\
\hline R- coefficient of multiple correlation; & $\mathrm{R}^{2}$ - coefficient of multiple determination, \\
p- significance level
\end{tabular}

Based on these results, it can be concluded that there is a high level of correlation of the criteria and predictor variables. 
Table 4 Partial contributions of significant predictors

\begin{tabular}{lcrc}
\hline Prediction variable & $\beta$ & $\mathrm{t}$ & $\mathrm{p}$ \\
\hline Agreeableness & .292 & 3.643 & .000 \\
Conscientiousness & .186 & 2.001 & .022 \\
Internality of negative situations & -.297 & -2.615 & .003 \\
Significance of negative situations & .283 & 2.527 & .021 \\
Total number of stressful events & .848 & 8.067 & .000 \\
Chronic stressors & .193 & 1.517 & .029 \\
Family problems & .299 & 2.231 & .011 \\
\hline
\end{tabular}

$\beta$-beta coefficient; $\mathrm{p}$ - significance level

The table above shows that the best predictor of the occurrence of emotional distress in adolescents is the total number of stressful events. The only variables presented in the table are those which are statistically significant predictors of emotional distress.

\section{DISCUSSION}

Two personality dimensions- Agreeableness and Conscientiousness have proven to be related to the emotional distress in adolescents. Those achieving higher scores- exhibit a greater likelihood of distress. The efforts of people with high Agreeableness to meet all the demands of the environment (Goldberg, 1990), which are in adolescence often mutually contradictory due to the often conflicting perceptions of peer environment and parental efforts, may represent a kind of source of emotional distress. People with highly expressed Agreeableness are more sensitive and emotional (Smederevac, 2000), which may constitute a factor that leads to certain situations from the environment that do not even have to have a direct relationship with them, experienced harder than others (Marić, 2009).

In people with pronounced Conscientiousness, we can expect somewhat more common emotional distress in adolescence. In adolescence, especially with the transition to high school, work duties are being expanded, the lessons become more complex, and the teachers' criteria higher. Highly conscientious people in this period are under increasing pressure, as trying to reach their new tasks and duties more efficiently (Smederevac, 2000). Much is anticipated out of these young people by the environment itself, primarily by parents and teachers, who are accustomed to the fact that conscious children achieve only success, which is also an additional source of distress (Marić, 2009).

When it comes to the relation between the way of attribution and the emergence of emotional distress, most significant contribution to the prediction of distress in adolescence are the dimensions of the internality of negative situations. So, in adolescents with a tendency of attributing the external causes to adverse events and the tendency of attributing greater 
significance to negative situations, we can expect more common emotional distress.

Personalities with a tendency of attributing the cause of the event to external factors are more prone to experience distress (Lazarus \& Folkman, 1984). A situation is more stressful in case the person assesses that the outcome is beyond his or her own scope of action. Such situation brings out the feeling of helplessness and inadequacy, which only further intensifies the degree of emotional distress (Sameroff, 2000; Zotović, 1999). Moreover, attaching greater importance to negative events, as shown by the research, predisposes young people to frequently experience emotional distress. Observing the causes of negative situations in external factors, a person distances from the problems and thus prevents the person from activating in solving situations (Novović et al., 2001; van Niekerk et al., 2016).

As presumed, the most important factors that lead to the occurrence of emotional distress in adolescence, have proved to be the factors from the environment. All three dimensions of life events- the total number, the time of occurrence and the type of the stressor predict the occurrence of emotional distress. The most important factor is the total number of events. Chronic and family stressors also provide a contribution to the prediction of emotional distress. All three groups of predictors indicate that with the increase in the total number of stressful situations, chronic and family stressors in particular, the likelihood of symptoms of emotional distress in adolescents increases. However, on the basis of a correlation study, it is not possible to exclude the possibility that adolescents with a higher level of emotional distress have a tendency to perceive and report a greater number of stressful experiences.

More frequent reports on stressful experiences have an adverse effect on the person's functioning, each time requiring new adaptation (Bensaba, 1999; Tucker, 2000). What is specific for adolescence is that the number of stressful experiences, new and unknown situations and challenges increases at this age, and the risk of emotional distress increases (Cuffe et al., 2005; Harkness et al., 2008; Starr \& Joanne, 2008; Steinhausen et al., 2007; Utsey et al., 2008). The total number of stressful experiences is a more significant predictor of the emotional distress than the type of stressors (Rutter, 1981; Sameroff, 2000), which was confirmed in this study. Stressful experiences of chronic character represent a specific type of threat to the emotional functioning of adolescents. Stressful events of this type continuously exhaust the defence potential of a young person (Tucker, 1996). In adolescence risk from the effects of smaller, but everyday stressors is particularly increased, given that young people of this age tend to experience a lot of things very dramatically and to violently react to them (Conger et al., 2003; Marić, 2009; Wenar, 2003).

Among the kinds of the tested stressful experiences, contributors to the prediction of emotional distress in adolescence are family stressors. 
These findings agree with the development theories, which emphasize the value of adequate growing up in a family context (Rutter, 1981; Wenar, 2003). Poor family relations represent a major obstacle to the proper development of adolescents, since in those circumstances young people usually do not get enough support from the parents (Petersen et al., 1992; Conger et al., 2003). It is of particular risk to for parents to reject and abuse (Harkness et al., 2008). A significant factor in the appearance of emotional distress in adolescents are incomplete families- cases of divorce, illness, death of a parent (Craword, Cohen, Midlarsky, \& Brook, 2001; Meltzer, 2000). Frequent conflicts among parents represent a major source of emotional distress for adolescents (Forehand, Kotchick, \& Biggar, 1998), as well as the difficult material situation of the family (Graber, 2004). Inadequate family environment leads to growing up at risk. The emotional distress that occurs in response to family problems is usually long-term (Conger et al., 2003; Graber et al., 1997).

The results of this study confirmed the assumption of diathesis-stress model (Joiner \& Schmidt, 1995; Sameroff, 2000), according to which emotional distress in adolescence has multifactorial nature. Stressful life experiences and life events showed to be the most important factors- the total number of events best predicted the emergence of emotional distress in young people. It can be concluded that the occurrence of emotional distress in adolescents is largely reactive, which was not an unexpected finding, since it is a non-clinical population of young people, who do not face any significant changes in the structure of personality that would indicate a tendency towards psychopathology. In particular, the occurrence of emotional distress in adolescence is influenced by internal factors that create individual differences in responses to similar life experiences.

The research of the factors that contribute to emotional distress in adolescence expands scientific knowledge about the nature of this phenomenon. These findings have their practical implications, which are reflected in the possibility of their application in the field of primary prevention and mental health of young people. By increasing the insight into the factors that contribute to emotional distress in adolescents, the growth possibilities of identifying risks in specific cases, while the continuation of this study would be to develop and evaluate appropriate prevention programs, with the aim of preserving and improving emotional functioning in adolescence.

\section{REFERENCES}

Abramson, L., Seligman, M.E.P., \& Teasdale, J.D. (1978). Learned helplessness in humans: critique and reformulation. Journal of Abnormal Psychology, 87, 49-74.

Aliik, J., \& Realo, A. (1997). Emotional experience and its relation to the five-factor model in Estonian. Journal of Personality, 65, 625-647. 
Belsley, D.A., Kuh, E. \& Walsch, R.E. (2004). Regression diagnostics: identification influential data and sources of collinearity. New York: Wiley-Interscience.

Bensaba, S. (1999). Stres je život [Stress is life]. Beograd: Zavod za udžbenike i nastavna sredstva.

Burns, S. (1997). The medical basis of stress, depression, anxiety, sleep problems, and drug use. Retrieved on Mart 24, 2003 from the World Wide Web: http://www. teachhealth.com/index.html.

Burns, M.O., \& Seligman, M.E.P. (1991). Explanatory style, helplessness, and depression. Handbook of social and clinical psychology. In C.R. Snyder (Ed.), The Health Perspective (pp. 267-280). New York: Academic Press.

Conger, R.D., Elder, G.H.J., Kim, K.J., \& Lorenz, F.O. (2003). Reciprocal influences between stressful life events and adolescent internalizing and externalizing problems. Child Development, 74(1), 127-143.

Costa, P.T., \& McCrae, R.R. (1980). Influence of extraversion and neuroticism on subjective well-being: happy and unhappy people. Journal of Personality and Social Psychology, 152, 668-678.

Crawford, T.N., Cohen, P., Midlarsky, E., \& Brook, J.S. (2001). Internalizing symptoms in adolescents: gender differences in vulnerability to parental distress and discord. Journal of Research on Adolescence, 11, 95-118.

Cuffe, S.P., McKeown, R.E., Addy, C.L., \& Garrison, C.Z. (2005). Family and psychosocial risk factors in a longitudinal epidemiological study of adolescents. Journal of the American Academy of Child and Adolescent Psychiatry, 44, 121-129.

David, J.P., Green, P.J., Martin, R., \& Suls, J. (1997). Differential roles of neuroticism, extraversion, and event desirability formood in daily life: an integrative model of top-down and bottom-up influences. Journal of Personality and Social Psychology, 73, 149-159.

Forehand, R., Biggar, H., \& Kotchick, B.A. (1998). Cumulative risk across family stressors: short- and long-term effects for adolescents. Journal of Abnormal Child Psychology, 26, 119-128.

Goldberg, L.R. (1990). An alternative "description of personality": the Big Five factor structure. Journal of Personality and Social Psychology, 59, 1216-1229.

Graber, J.A. (2004). Internalizing problems during adolescence. In R.M. Lerner \& L. Steinberg (Eds.), Handbook of adolescent psychology ( $2^{\text {nd }}$ Ed., pp. 587-626). Hoboken, New Jersey: John Wiley \& Sons, Inc.

Grossman, F.K., Anderson, L., Sakurai, M., Finnin, L., Fox, M., \& Beinashowitz, J. (1990). Risk and resilience in young adolescents. Resilient Adolescent Project. Boston, Boston University \& Quincy Public School.

Harris, J.A. \& Lucia, A. (2003). The relationship between self-reportmood and personality. Personality and Individual Differences, 35, 1903-1909.

Harkness, K.L., Lumley, M.N., \& Truss, E. (2008). Stress generation in adolescent depression: the moderating role of child abuse and neglect. Journal of Abnormal Child Psychology, 36(3), 421-432.

Headey, B., \& Wearing, A. (1989). Personality, life events, and subjective well-being: Toward a dynamic equilibrium model. Journal of Personality and Social Psychology, 57, 731-739.

Hjelle, L.A. (1992). Current research and applications in personality theories. New York: McGraw-Hill, Inc.

John, O.P., Donahue, E. M., \& Kentle, R. L. (1991). The Big Five Inventory-versions 44 and 54. Berkley, CA: University of California, Berkley, Institute of Personality and Social Research.

Joiner, T.E., \& Schmidt, N.B. (1995). Dimensions of perfectionism, life stress, and depressed and anxious symptoms: prospective support for diathesis-stress but not 
specific vulnerability among male undergraduates, Journal of Social and Clinical Psychology, 14, 165-183.

Joiner, T.E., \& Wagner, K.D., (1995). Attributional style and depression in children and adolescents: A meta-analytic review. Clinical Psychology Review, 15, 777-798.

Karevold, E. (2008). Family stress and child's temper extremes contribute to anxiety and depression in children and young people. Science Daily, Oslo: Folkehelseinstituttet, NIPH- Norwegian Institute of Public Health

Krackow, E., \& Rudolph, K.D. (2008). Life stress and the accuracy of cognitive appraisals in depressed youth. Journal of Clinical Child and Adolescent Psychology, 37 (2), 376-385.

Lazarus, R. \& Folkman, S. (1984). Stress, appriasal, and coping. New York: Springer.

Larsen, R.J. \& Ketelaar, T. (1991). Personality and susceptibility to positive and negative emotional states. Journal of Personality and Social Psychology, 61(1), 132-140.

Lovibond, S.H., \& Lovibond, P.F. (1995). Manual for the Depression Anxiety Stress Scales $\left(2^{\text {nd }}\right.$ Ed.). Sydney: Psychology Foundation.

Lucas, R.E., \& Baird, B.M. (2004). Extraversion and emotional reactivity. Journal of Personality and Social Psychology, 86, 473-485.

Lucas, R.E., \& Fujita, F. (2000). Factors influencing the relation between extraversion and pleasant affect. Journal of Personality and Social Psychology, 79, 1039-1056.

Marić, M. (2009). Prediktori afektivnih odgovora kod nekliničke populacije adolescenata [Predictors of affective responses in non-clinical population of adolescents]. (Magister thesis). Novi Sad: Faculty of Philosophy.

McCrae, R.R., \& Costa, P.T. (1991). Adding liebe und arbeit: the full five-factor model and well-being. Personality and Social Psychology Bulletin, 17, 227-232.

McCullough,G., Huebner, E.S. \& Laughlin, J.E. (2000). Life events, self-concept, and adolescents' positive subjective well-being. Psychology in the Schools, 37(3), 281-290.

Meltzer, H. (2000). Mental health of children and adolescents in Great Britain. London: The Stationery Office.

Novović, Z. i Biro, M. (1996). Iluzija kontrole kao prepreka apetitivnoj naučenoj bespomoćnosti [Illusion of the control as the barrier to the appetitive acquired helplessness]. Psihologija, 1, 21-34.

Novović, Z., Kosanović, B., Biro, M. i Smederevac, S. (2001). Veza između atribucionog stila, anksioznosti i depresije [Correlation between attributional style, anxiety and depression]. Psihologija, 1-2, 139-154.

Paykel, E.S. (1982). Life events and early environment. In E.S. Paykel (Ed.), Handbook of affective disorders (pp.146-161). New York: Guilford Press.

Petersen, A.C., Compas, B.E., \& Brooks-Gunn, J. (1992). Depression in adolescence: current knowledge, research directions, and implications for programs and policy. New York, NY: Carnegie Corp. ERIC Document Reproduction Service.

Peterson, C., Semmel, A., von Baeyer, C., Abramson, L.Y., Metalsky, G.I., \& Seligman, M.E.P. (1982). The Attributional Style Questionaire. Cognitive Therapy and Research, 6, 287-299.

Petroska-Beška, V., Biro, M., Kostarova-Unkovska, L., Keramicieva, R., Joksimovic, S., Nikoloska, M., Rosandic, R., Simovska, V., Takašmanova-Sokolovska, T. (1995). Risk and resilience in refugee children and their adaptation to the new environment. Praha: Open Society Institute.

Pynoos, R.S. (1993). Traumatic stress and developmental psychopathology in children and adolescents. U J.M. Oldham, M.B. Riba, A. Tasman (Eds.), American psychiatric press review of psychiatry, 12, 205-238. Washington DC: American Psychiatric Press. 
Rudolph, K.D., \& Clark, A.G. (2001). Conception of relationships in children with depressive and aggressive symptoms: social-cognitive distortion or reality? Journal of Abnormal Child Psychology, 29, 41-56.

Rutter, M. (1981). Stress, coping, and development: some issues and questions. Journal of Child Psychology, Psychiatry and Allied Disciplines, 22, 323-356.

Sameroff, A.J. (2000). Developmental systems and psychopathology. Development and psychopathology, 12(3), 297-312.

Seligman, M.E.P. (1978). Comment and integration. Journal of Abnormal Psychology, 87, $165-179$.

Silver, R.L. \& Worthman, C.B. (1979). Coping with undesirable life events. In J. Garber \& M.E.P. Seligman (Eds.), Human helplessness: theory and applications, 12 (pp. 279-340). New York: Academic Press.

Smederevac, S. (2000). Istraživanje faktorske strukture ličnosti na osnovu leksičkih opisa ličnosti u srpskom jeziku [The research of the factor structure of personality on the basis of lexical description of personality in the Serbian language]. (Doctoral dissertation). Novi Sad: Faculty of Philosophy.

Stark, K.D., Humphrey, L.L., Laurent, J., Livingston, R., \& Christopher, J. (1993). Cognitive, behavioral, and family factors in the differentiation of depressive and anxiety disorders during childhood. Journal of Consulting and Clinical Psychology, 61, 878-886.

Starr, L., \& Joanne, D. (2008). Differentiating interpersonal correlates of depressive symptoms and social anxiety in adolescence: implications for models of comorbidity. Journal of Clinical Child and Adolescent Psychology, 37(2), 337-349.

Steinhausen, H.C., Haslimeier, C., \& Metzke, C.W. (2007). Psychosocial factors in adolescent and young adult self-reported depressive symptoms: causal or correlational associations? Journal of youth and adolescence, 36, 89-100.

Szabó, M., \& Lovibond, P.F. (2006). Anxiety, depression and tension/stress in children. Journal of Psychopathology and Behavioral Assessment, 28(3), 195-205.

Tucker, C. (1996). Psychological self-help. Illinois: Dwight.

Tucker, C. (2000). Stress, trauma, anxiety, fears and psychosomatic disorders. Retrieved May 10, 2003 from the World Wide Web: http://mentalhelp.net/psyhhelp/ chap $5 /$ chap $5 \mathrm{c} / \mathrm{htm}$.

Utsey, S.O., Giesbrecht, N., Hook, J., \& Stanard, P.M. (2008). Cultural, sociofamilial, and psychological resources that inhibit psychological distress in African Americans exposed to stressful life events and race-related stress. Journal of Counseling Psychology, 55, 49-62.

van Niekerk, R. E., Klein, A. M., Allart-van Dam, E., Hudson, J. L., Rinck, M., Hutschemaekers, G.J. M., Becke, E.S. (2016). The role of cognitive factors in childhood

social anxiety: social threat thoughts and social skills perception. Cognitive Therapy Research. DOI 10.1007/s10608-016-9821-x

Zotović, M. (1999). Ratni stres. Postoje li otporna deca? [War stress. Are there resilient children?]. Belgrade: Andrejević Foundation.

Watson, D., \& Clark, L.A. (1992). On traits and temperament: general and specific factors of emotional experience and their relation to five-factor model. Journal of Personality, 60, 441-476.

Wenar, C. (2003). Razvojna psihopatologija i psihijatrija: od dojenačke dobi do adolescencije [Developmental psychopathology and psychiatry: from infancy to adeolscence]. Jastrebarsko: Naklada Slap. 


\title{
ЛИЧНОСТ, КОГНИЦИЈА И ЖИВОТНИ ДОГАЪАЈИ КАО ПРЕДИКТОРИ ЈАВЉАЬА ЕМОЦИОНАЛНОГ ДИСТРЕСА НА АДОЛЕСЦЕНТСКОМ УЗРАСТУ
}

\author{
Миа Марић, Марија Сакач \\ Универзитет у Новом Саду, Педагошки факултет у Сомбору, Сомбор, Србија
}

\section{Резиме}

Циљ рада био је испитивање доприноса особина личности, когнитивног стила и животних догађаја предвиђању симптома емоционалног дистреса код адолесцената. Узорком је обухваћено 300 испитаника, ученика 2. и 3. разреда средње школе. У анализу су уврштени показатељи пет димензија личности: Неуротицизма, Екстраверзије, Отворености, Пријатности и Савесности; атрибуционих димензија: контролабилности, интерналности, стабилности, глобалности узрока и значајности ситуација, број, врста и време јављања животних догађаја, те степен изражености емоционалног дистреса код адолесцената.

Као теоријски оквир узети су у обзир модел личности „Великих пет”, теорије атрибуција и животних догађаја, као и концепције настанка негативних емоционалних одговора у адолесценцији. У дијатеза-стрес моделима истиче се да је појава негативних емоционалних реакција у адолесценцији сложене природе и да на њу утиче већи број унутрашњих и спољашњих фактора.

Од инструмената су примењени упитник „Великих пет” (BFI, John et al., 1991), упитник атрибуционог стила (ASQ, Peterson et al., 1982), модификована Скала ризика (Risc Scale, Grossman et al., 1990), као и скала за мерење емоционалног дистреca, у оквиру упитника ДАСС-21 (Lovibond \& Lovibond, 1995). Сви примењени инструменти су у овом истраживању показали задовољавајуће метријске карактеристике.

Најзначајнијим показатељима предвиђања емоционалног дистреса код адолесцената, у овом истраживању, показали су се животни догађаји, при чему највећи допринос појави дистреса пружа укупан број догађаја. Могућност појаве емоционалног дистреса повећава се са појавом хроничних стресора и породичних проблема. У значајној мери са појавом дистреса повезане су и димензије личности Пријатност и Савесност, као и атрибуционе димензије екстерналност и значајност за негативне ситуације.

Добијени резултати имају и своје практичне импликације, које се огледају у могућности њихове примене у домену примарне превенције и заштите менталног здравља младих. Са порастом увида у чиниоце који доприносе појави емоционалног дистреса код адолесцената, расту могућности препознавања ризика у конкретним случајевима, а као наставак овог истраживања могући су и развој и евалуација одговарајућих превентивних програма, са циљем очувања и унапређења менталног, а посебно емоционалног функционисања у адолесценцији. 